\title{
ARTICLES
}

\section{A COMPARATIVE STUDY TO ASSESS THE KNOWLEDGE AND ATTITUDE AMONG PARENTS REGARDING EARLY DETECTION OF JUVENILE DELINQUENCY IN RURAL AND URBAN AREAS OF WEST BENGAL. INDIA.}

Mrs. Payel Bose* \& Dr. Rajwant Kaur Randhawa**

*Research Scholar, Associate Professor, Gouri Devi College of Nursing, Durgapur, West Bengal, India. **Guide, Professor Desh Bhagat University, College of Nursing, Mandi Gobindgarh, Punjab, India. DOI: http://doi.org/10.47211/trr.2021.v07i02.004

ABSTRACT:

Delinquency is unwelcomed action, omission or moral behavior of a juvenile, which is socially not permitted in any society. Generally it means that if the child fails to meet certain social obligations anticipated from them by the Standards and Goals made by the society. Aim: to assess the knowledge and attitude among parents regarding early detection of juvenile delinquency in rural and urban areas. Materials and Methods: $A$ quantitative non-experimental research approach, comparative research design was used. Total samples were 1000 parents (500 in rural and 500 in urban areas) of West Bengal were selected by non-probability purposive sampling technique. Data was collected by using self-structured knowledge questionnaire and self-structured attitude scale. Results: The study results depicted that the parents in urban areas have more average knowledge and negative attitude than rural areas regarding early detection of juvenile delinquency. Conclusion: the study concluded that parents in urban areas have more knowledge and negative attitude than parents in rural areas.

Key Words: early detection of Juvenile delinquency, Parents.

\section{ABOUT AUTHORS:}

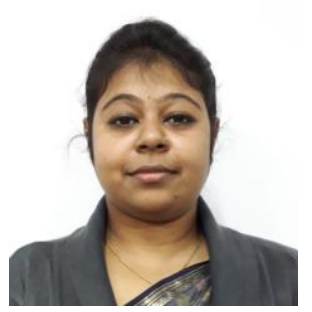

Author Mrs. Payel Bose is Research Scholar, Associate Professor, Gouri Devi College of Nursing, Durgapur, West Bengal, India.

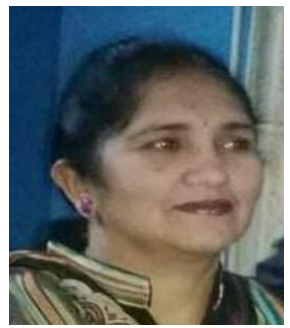

Author Dr. Rajwant Kaur Randhawa is Guide, Professor Desh Bhagat University, College of Nursing, Mandi Gobindgarh, Punjab, India. 


\section{ARTICLES}

\section{INTRODUCTION:}

\section{"Children must be taught what to think, not what to think."}

Margaret Mead

Juvenile Delinquency is an unwelcomed action, omission or moral behavior of a juvenile, which is socially not permitted in any society. Generally in it the child fails to meet certain social obligations anticipated in the society. The juvenile delinquent is behavioral disorder which is generally defined as "a child trying or pretending to act like a grown up or adult". The action of the child can be seen as a childish foolish behavior but it can cause serious worry and concern. There is a narrow difference between a delinquent child and a normal child and the behavior of an anxious person is the deciding factor among a cheerful act and delinquency. The cases registered under various sections of IPC crimes against juveniles in conflict with law in 2014 have increased by $5.7 \%$ over 2013 as 31,725 cases against juveniles were registered under IPC crimes during 2013 which increased to a total number of 33,526 such cases in 2014. The highest number of cases registered against juveniles were reported under the crime head which included theft" (20.0\%), rape" (5.9\%) and "grievous hurt" \& 'assault on women with intent to outrage her modesty' (4,7\% each). The incidence is increasing worldwide and in India, the majority of the crime was done by youths who are in the age group of 15-18 years. Recently crime rate against females are increasing. In India juvenile delinquency was increased in the year 1995 the crime rate was 9766, in short duration of 6 years crime rate increased to 16,509 and during 2005 its number is again been raised to18, 939. The concept of juvenile delinquency is much complied and varies from country to country and even in the various provinces of the same country. There is no definition that may be used worldwide because the sociologists, psychologists and legalists define 'Juvenile Delinquency' in their own way. It varies from nation to nation, for what is forbidden to do at one place, can be allowed in the other place.

\section{OBJECTIVES}

1. To assess the knowledge regarding early detection of juvenile delinquency among parents of rural and urban areas.

2. To assess the attitude regarding early detection of juvenile delinquency among parents of rural and urban areas.

3. To compare the knowledge and attitude regarding early detection of juvenile delinquency among parents of rural and urban areas

4. To find out the association of knowledge score among parents regarding early detection of juvenile delinquency in rural and urban areas with demographic variables.

5. To find out the association of attitude score among parents regarding early detection of juvenile delinquency in rural and urban areas with demographic variables.

\section{MATERIALS AND METHODS}

Research approach and design

A quantitative Non experimental research approach, comparative research design was considered to be the most appropriate.

Variables of the study

Research Variable: Juvenile delinquency

Demographic variable: knowledge and attitude of parents

Research Setting

The setting for the present study was in rural and urban areas, West Bengal.

Rural Area of West Bengal including District:- Purba Bardhaman

Urban Area of West Bengal including District:- Paschim Bardhaman

The selection of this areas were done on the basis of geographical proximity, feasibility of conducting the study, economy in terms of time, easy transport facilities and availability of sample.

\section{Target Population}

The target population for study was the parents of West Bengal

Sample size and Sampling Technique:

The total sample size for the study comprises of 1000 parents i.e. 500 in rural area and 500 in urban area of West Bengal. Non probability purposive sampling technique was used for sampling. 


\section{ARTICLES}

Inclusion criteria

1. Parents of children 6-18 years.

2. Sample size $\mathbf{1 0 0 0}$ parents. 500 in rural and 500 in urban area

3. Parents who will be present at the time of data collection.

4. Parents who will be willing to participate at the time of data collection.

\section{Exclusion criteria}

1. Absent at the time of data collection.

2. Not willing to participate.

Selection and development of tool:

A Self structured knowledge questionnaire and Self structured attitude scale was prepared for assessing the knowledge and attitude of Parents regarding early detection of juvenile delinquency.

It was divided into three sections:

\section{PART A: STRUCTURED DEMOGRAPHIC SHEET}

\section{PART B: SELF STRUCTURED KNOWLEDGE QUESTIONNAIRE}

It comprised of 30 multiple choice questions with every correct answer was awarded as 'one' and incorrect answer 'zero'.

Table: 1. Criterion measurement for knowledge:

\begin{tabular}{lll}
\hline S.No & Criterion measurement & Score \\
\hline 1. & Good & $21-30$ \\
2 & Average & $11-20$ \\
3 & Below average & $0-10$ \\
\hline
\end{tabular}

\section{PART C: SELF STRUCTURED ATTITUDE SCALE}

It comprised of 30 questions in Likert scale form having 4 options that are given as follows: strongly disagree = 1, disagree $=2$, agree $=3$, strongly agree $=4$. lowest score is 30 and highest is 120 .

Table: 2. Criterion for attitude measurement:

\begin{tabular}{lll}
\hline S.No. & CRITERION MEASUREMENT & SCORE \\
\hline 1. & Positive attitude & $91-120$ \\
2 & Negative attitude & $61-90$ \\
3. & Nullified attitude & $30-60$ \\
\hline
\end{tabular}

\section{DATA ANALYSIS}

Data analysis was based on the objectives stated in the study by using descriptive and inferential statistics by calculating the frequency, percentage, t-test, ANOVA. Bar graphs were used for pictorial presentation.

\section{RESULTS}

The sample characteristics: in relation to age, it was found that in rural area maximum were in the age group of $26-30$ years (38\%), followed by $31-35$ years (34\%), $21-25$ years (22\%) and above 36 years (6\%); where as in urban area maximum were in age group of $31-35$ years (38\%), followed by $26-30$ years (36\%), $21-25$ years (20\%) and above 36 years $(6 \%)$. In relation to gender the percentage distribution of parents in both rural and urban areas was found that maximum were females (70\% and $68 \%$ ) followed by males (30\% and $32 \%$ ). While as per percentage distribution of parents according to religion, it was found that maximum were in (62\%) Hindu, followed by (35\%) Sikh, followed by (3\%) Muslim and followed by Christian (0\%). With relation to Education qualification the percentage distribution of parents was found that in rural area Majority were higher secondary passed $(77 \%)$ followed by secondary $(14 \%)$, graduate $(8 \%)$; whereas the percentage distribution of parents in urban area was found that majority were graduates (63\%), followed by Secondary (12\%), higher secondary (19\%), Post graduate (6\%). As per Employment status the percentage distribution of parents was found that majority were farmer (83\%), followed by private sector (8\%), Govt. sector $(7 \%)$ and unemployed (2\%); where as in Urban area the majority were found working in Private sector (68\%), followed by Farmer (25\%), Govt. sector (7\%) and unemployed (0\%). As per Area of residence the percentage distribution of rural areas was $100 \%$ and the percentage distribution of urban areas was $100 \%$. According to type of family the percentage distribution shows that majority of parents in rural and urban areas were living in nuclear family (55\% and $65 \%$ ), followed by joint family (45\% and $35 \%$ ). With respect to Sources of information about juvenile delinquency the percentage distribution was found that in both rural and urban areas majority were found to be from social media( $43 \%$ ), followed by television (29\%), friends and family (16\%), news paper (11\%). As per child tendency of absenteeism 


\section{ARTICLES}

the percentage distribution in rural areas was found that for Yes it was $34 \%$ and for No $66 \%$; where as in urban areas the percentage distribution for Yes was $23 \%$ and for No $77 \%$.

FINDINGS AS PER THE OBJECTIVES OF THE STUDY:

OBJECTIVE 1: TO ASSESS THE KNOWLEDGE REGARDING EARLY DETECTION OF JUVENILE DELINQUENCY AMONG PARENTS OF RURAL AND URBAN AREAS.

The study represents the knowledge score of parents regarding early detection of juvenile delinquency. Here, the parents in both rural and urban areas have Average knowledge regarding early detection of juvenile delinquency ( $72 \%$ in rural areas and $76 \%$ in urban areas) followed by good $(2.8 \%$ in rural areas and $1.8 \%$ in urban areas); below average (25.2\% in rural areas and $22.2 \%$ in urban areas). This result is supported by the study done by Sarah BD (2009), the findings strongly support that the population have less knowledge regarding juvenile delinquency and have negative attitude towards it.

Table 3 represents the knowledge regarding early detection of juvenile delinquency among the parents in rural areas and urban areas.

\begin{tabular}{cccccc}
\hline \multicolumn{6}{c}{ CRITERIA MEASURE OF KNOWLEDGE SCORE N=1000 } \\
( Rural= 500, Urban= 500) \\
\hline CATEGORY & SCORE & RURAL & RURAL & URBAN & URBAN \\
& & $(\mathbf{f})$ & $\mathbf{( \% )}$ & (f) & (\%) \\
GOOD & $(21-30)$ & 14 & $2.8 \%$ & 9 & $1.8 \%$ \\
AVERAGE & $(11-20)$ & 360 & $72 \%$ & 380 & $76 \%$ \\
BELOW AVERAGE & $(0-10)$ & 126 & $25.2 \%$ & 111 & $22.2 \%$ \\
\hline
\end{tabular}

Objective 2: To assess the attitude regarding early detection of juvenile delinquency among parents of rural and urban areas.

The study represents the attitude score regarding early detection of juvenile delinquency among the parents in rural areas and urban areas. Here it is found that the parents in both rural areas and urban areas had Negative attitude i.e., $75.4 \%$ in rural area and $77.2 \%$ in urban areas regarding juvenile delinquency, followed by positive attitude $24.6 \%$ in rural areas and $22.8 \%$ in urban areas. This was supported by the study of Celeste simões $(2013)^{7}$ was conducted the descriptive study on attitude of parents regarding juvenile delinquent behavior in higher secondary students. Samples were 200 parents of higher secondary students. The result showed that $57 \%$ of the parents had negative attitude toward juvenile delinquent behavior, $33 \%$ of the parents agree that juvenile delinquent behavior can be manageable if taken under consideration, $10 \%$ had no comments juvenile delinquent behavior.

Table 4 represents the attitude regarding early detection of juvenile delinquency among parents of rural and urban areas.

\begin{tabular}{cccccc}
\hline \multicolumn{7}{c}{ CRITERIA MEASURE OF ATTITUDE SCORE N=1000 } \\
(Rural= 500, Urban= 500)
\end{tabular}




\section{ARTICLES}

Objective 3: To compare the knowledge and attitude regarding early detection of juvenile delinquency among parents of rural and urban areas

The study represents the comparison of knowledge score in rural and urban areas. In rural area the mean $\pm S$.D. is $12.79 \pm 3.527$ and in urban area the mean \pm S.D. is $12.87 \pm 3.151$, these both results are non significant at significance level of 0.05 . Whereas the comparison of attitude score in rural and urban areas represents that in rural areas the mean $\pm S$.D. is $86.97 \pm 5.885$ which is more than in urban area mean $\pm S$.D. is $86.91 \pm 5.755$, these both results are non significant at significance level of 0.05 . It is supported by the study done by 0 kon $(2016)^{6}$, the majority held awareness regarding juvenile delinquents.

Table 5 represents the comparison of knowledge score in rural and urban areas. $\mathbf{N}-500$

\begin{tabular}{|c|c|c|c|c|c|c|c|c|c|}
\hline \multicolumn{2}{|c|}{ Unpaired T Test } & \multirow{2}{*}{$\begin{array}{l}\text { Mean } \\
\text { Score }\end{array}$} & \multirow{2}{*}{$\begin{array}{l}\text { S.D. } \\
3.527\end{array}$} & \multirow{2}{*}{$\begin{array}{l}\mathbf{N} \\
500\end{array}$} & \multirow{2}{*}{$\begin{array}{l}\text { Mean F } \\
42.63\end{array}$} & \multirow{3}{*}{$\begin{array}{l}\text { Unpaired } \\
\text { Test }\end{array}$} & \multirow{2}{*}{$\begin{array}{l}\mathbf{P} \\
\text { value } \\
0.719\end{array}$} & \multirow{2}{*}{$\begin{array}{l}\begin{array}{l}\text { Table } \\
\text { Value at } \\
0.05\end{array} \\
1.962\end{array}$} & \multirow{3}{*}{$\begin{array}{l}\text { Result } \\
\begin{array}{l}\text { Non } \\
\text { Significant }\end{array}\end{array}$} \\
\hline \multirow{2}{*}{$\begin{array}{l}\text { KNOWLEDGE } \\
\text { SCORE }\end{array}$} & RURAL & & & & & & & & \\
\hline & URBAN & 12.87 & 3.151 & 500 & 42.89 & & 0.119 & & \\
\hline
\end{tabular}

Maximum $=30$ Minimum $=0$

$p<0.05$ level of significance

Table 6 represents the comparison of attitude score in rural and urban areas. N-500

\begin{tabular}{|l|l|l|l|l|l|l|l|l|}
\hline \multicolumn{2}{|l|}{ Unpaired T Test } & $\begin{array}{l}\text { Mean } \\
\text { Score }\end{array}$ & S.D. & N & $\begin{array}{l}\text { Unpaired } \\
\text { Test }\end{array}$ & P value & $\begin{array}{l}\text { Table Value } \\
\text { at } \mathbf{0 . 0 5}\end{array}$ & Result \\
\hline $\begin{array}{l}\text { ATTITUDE } \\
\text { SCORE }\end{array}$ & RURAL & 86.97 & 5.885 & 500 & 0.158 & 0.875 & 1.962 & $\begin{array}{l}\text { Non } \\
\text { Significant }\end{array}$ \\
\cline { 2 - 9 } & URBAN & 86.91 & 5.755 & 500 & & & &
\end{tabular}

Maximum $=120$ Minimum=30 $\mathbf{p}<0.05$ level of significance

Table 5 represents the comparison of attitude score among parents regarding early detection of juvenile delinquency in rural and urban areas with demographic variables.

Objective 4: To find out the association of knowledge score among parents regarding early detection of juvenile delinquency in rural and urban areas with demographic variables.

In rural areas there was significant association with religion, as statistically analyzed with ANOVA test, $\mathrm{F}=3.113^{*}$ and type of family as statistically analyzed with ANNOVA test, $\mathrm{F}=4.235^{*}$. But there was no significant association between knowledge score with age, gender, qualification, employment status, area of residence, source of information, child tendency of absenteeism. In urban areas there was significant association with source of information, as statistically analyzed with ANOVA test, $F=3.113^{*}$ and type of family as statistically analyzed with ANNOVA test, $F=4.23^{*}$. But there was no significant association between knowledge score with age, gender, religion, qualification, employment status, area of residence, child tendency of absenteeism. It is supported by the study done by Lahey BB (2012). ${ }^{8}$ this suggests that the association between parental knowledge and future delinquency is not solely spurious; rather parental knowledge and limit setting are both meaningful predictors of future delinquency.

Objective 5: To find out the association of attitude score among parents regarding early detection of juvenile delinquency in rural and urban areas with demographic variables.

In rural areas there was no significant association between attitude score with age, gender, religion, qualification employment status, area of residence, type of family, source of information and child tendency of absenteeism at 0.05 level of significance. In urban areas there was no significant association between attitude score with age, gender, religion, qualification employment status, area of residence, type of family, source of information and child tendency of absenteeism at 0.05 level of significance. It is supported by the study done by $\mathrm{Miners} \mathrm{MH}$, Munns R (2011). ${ }^{9}$ The results indicate no association between the socio demographic variables the attitude scale. 


\section{ARTICLES}

\section{REFERENCES:}

1. National crime research bureau, 2014. crime in India compendium, New Delhi. [Google Data Base]

2. Pegionner Coley. Juvenile delinquency incidence in India. Available from: http:// social justice.nic.in/sdd/2-7.php. [Google Scholar]

3. Polit D F, Beck C T. (2017) Nursing research generating and Assessing Evidence For Nursing Practice.10 edition. New Delhi: Wolters kluwer health Philadelphia; 88-89p.

4. Barker L. The Effects of Juvenile Delinquency.

5. http://www.ehow.com/about_5108646_effects-juvenile-delinquency. [Google Scholar]

6. Sarah B.D and J.M.Nicholson. Teachers' knowledge of children's exposure to family risk factors: accuracy and usefulness. Journal of School Psychology [serial online] Jan 2009 (cited on 15 Nov 2015); 43(1): 23-38. Available from URL: http:/www.eric.ed.gov. [Google Scholar]

7. Okon, Esther Edet.knowledge and awareness of juvenile delinquency Department of Social Work, University of Nigeria Nsukka, Aug 2016; 14 (2): 33-42 Available from URL: http//www.researchgate.net [ Google Scholar], [Research Gate]

8. Celeste SIMÕES, Margarida G. MATOS \& Joan M. Batista-Foguet Juvenile Delinquency: Analysis Of Risk And Protective Factors Using Quantitative And Qualitative Methods technical University Of Lisbon.Dec.2013.Csimoes@Fmh.Utl.Pt. [Google Scholar] [Research Gate]

9. Lahey BB, Van Hulle CA, D'Onofrio BM, Rodgers JL, Waldman ID. Is parental knowledge of their adolescent offspring's whereabouts and peer associations spuriously associated with offspring delinquency J Abnorm Child Psychol. 2008 Aug; V.36(6), P.807-23.[Google Scholar], [Research Gate]

10. Miners $\mathrm{MH}$, Munns R. Isolation and normlessness attitudinal comparison. International Journal of Offender Therapy and Comparative Criminology, 49(5), August 2014. [Google Scholar] [Research Gate] https://www.researchgate.net/publication/264939643 